\title{
Omalizumab vs. placebo in the management of chronic idiopathic urticaria: a systematic review
}

\author{
Diana C Carrillo ${ }^{1 *}$, Mario Sanchez Borges ${ }^{2}$, Elizabeth Garc? $a^{3}$, Eduardo Egea ${ }^{4}$ and Carlos D Serrano ${ }^{1,5^{*}}$
}

\begin{abstract}
Objectives: To examine the evidence derived from randomized controlled clinical trials on the efficacy and safety of omalizumab compared to placebo in controlling symptoms of chronic idiopathic urticaria/chronic spontaneous urticaria (CIU/CSU).

Data source: The electronic databases PubMed, Medline, EMBASE, Biomed Central, The Cochrane Central Register of Controlled Trials (CENTRAL), Wiley, OVID, and HighwirePress were reviewed. The date limit was set to May 31th, but it was extended to September 30th of 2014 due to a new publication. No language restriction was used. The articles included were randomized trials controlled with placebo in individuals older than 12 years diagnosed with CIU/CSU refractory to conventional treatment, the intervention being, omalizumab at different doses, and the comparison, placebo. The primary outcome was symptom improvement according to the weekly score of urticaria severity (UAS7), the itch severity score (ISS), the weekly score of number of urticarial lesions, the dermatology life quality index, and the chronic urticaria quality of life questionnaire (CU-QoL). Databases were searched using the following Mesh or EMTREE key words including as intervention omalizumab or humanized monoclonal antibody, compared to placebo and the disease of interest urticaria or angioedema. The title, abstract and article were reviewed by two independent investigators, according to the selection criteria in each of the databases. An assessment of the quality of the articles was performed according to the bias tool from the studies of the Cochrane Collaboration. Information such as author data, date of study, number of participants, interventions, dose and frequency of administration, comparison, time of follow-up, measurements of weekly score of urticaria activity, pruritus severity score, weekly urticarial lesions, percentage of angioedema and post-treatment change were extracted. Frequency of adverse events and the ones suspected to be caused by the intervention drug were included.
\end{abstract}

Results: 770 records were identified in all databases described. 720 were eliminated for failing to meet the inclusion criteria in the first review or for duplicate records. 24 articles were reviewed by abstract, 18 additional articles were further removed, leaving 6 records for inclusion. An experimental study was excluded because it wasn $t$ randomized. Five studies were finally included, with 1117 patients, of these 831 received a dose of omalizumab of $75 \mathrm{mg}$ (183 patients, 16.38\%), $150 \mathrm{mg}$ (163 patients, 14.59\%), $300 \mathrm{mg}$ (437 patients, 39.12\%) or $600 \mathrm{mg}$ (21 patients, 1.8\%), as a single dose, or every 4 weeks until 24 weeks maximum. The average age was 42.07 years, predominantly female gender and white ethnicity. It was observed that the use of omalizumab $300 \mathrm{mg}$ lowered the weekly scores of urticarial activity in 19.9 vs. 6.9 on placebo ( $p<0.01$ ), 19 vs 8.5 and 20.7 vs 8.01 in three studies, the weekly ISS ( -9.2 vs. $-3.5, p<0.001$, -9.8 vs $-5.1 p<0.01,-8.6$ vs -4.0 and -9.4 vs $-3.63 p<0.001$ in four studies), and the percentage of angioedema-free days (omalizumab $95.5 \%$ vs. placebo $89.2 \% \mathrm{p}<0.001$, and $91.95 \%$ vs. $88.1 \% \mathrm{p}<0.001$ in two of the studies respectively).

Limitations: The different doses used throughout the study, time of administration and follow-up periods ranged from single dose to monthly dose for 24 weeks. Therefore no meta-analysis of the review was conducted.

(Continued on next page)

\footnotetext{
*Correspondence: diana_cristinac@hotmail.com; egea.eduardo@gmail.com

'Department of Internal Medicine, Fundaci?n Valle del Lili, Carrera 98 \#

18-49, Cali, Colombia

${ }^{5}$ Allergy Unit, Fundacion Valle del Lili, Carrera 98 \# 18-49, Cali, Colombia

Full list of author information is available at the end of the article
}

\section{Biomed Central}

? 2014 Carrillo et al.; licensee BioMed Central. This is an Open Access article distributed under the terms of the Creative Commons Attribution License (http://creativecommons.org/licenses/by/4.0), which permits unrestricted use, distribution, and reproduction in any medium, provided the original work is properly credited. The Creative Commons Public Domain Dedication waiver (http://creativecommons.org/publicdomain/zero/1.0/) applies to the data made available in this article, unless otherwise stated. 
(Continued from previous page)

Conclusions and implications of the main findings: Despite the limitations, it is considered that omalizumab $300 \mathrm{mg}$ is effective in treating chronic idiopathic urticaria refractory to $\mathrm{H} 1$ antihistamines. Further studies are required to determine the duration of effective treatment.

Registration number of the systematic review: CRD42014010029 (PROSPERO. International Prospective Register of Systematic Reviews).

Keywords: Antibodies, Monoclonal, Humanized, Urticaria, Angioedema

\section{Introduction}

Chronic idiopathic urticaria/chronic spontaneous urticaria (CIU/CSU), is a skin disease characterized by recurrent appearance of wheals, angioedema, or both, occurring at least twice a week for more than 6 weeks [1]. Its course is self-limiting with spontaneous remissions and relapses [2]. It is an important cause of morbidity and even though it has a very low risk of endangering life, it has a high impact on quality of life $[3,4]$. This disease affects at least $0.5-1.0 \%$ of the population and $40 \%$ may present urticarial lesions up to 10 years later [1,4-7].

The pathogenesis of CIU/CSU is not completely understood. It is considered that mast cell degranulation and histamine release play a major role, however, in more than half of the patients there is no established triggering allergic event that can be made responsible for the mast cell activation and so it is called chronic idiopathic (or spontaneous) urticaria [3,4]. In some cases the presence of immunoglobulin $\mathrm{G}$ antibodies to the high affinity receptor for IgE (FceRI) alpha subunit or to IgE itself has been documented $[2,4]$.

Treatment options are few and usually off-label [3]. The EAACI/GA ${ }^{2}$ LEN/EDF/WAO (European Academy of Allergology and Clinical Immunology, Global Allergy and Asthma European Network, European Dermatology Forum and World Allergy Organization, respectively) guidelines recommend the use of non-sedating antihistamines at conventional dose as a first line of treatment, the increase of their dosage up to fourfold as a second line, and the use of Omalizumab, montelukast, or systemic immunosuppressants as cyclosporine A for the third line of treatment, and corticosteroids for a short course for disease exacerbations [8].

For those patients refractory to standard medical management, the use of omalizumab, an IgG1k type monoclonal antibody that binds to free Immunoglobulin $\mathrm{E}$ in the blood, has been proposed as a treatment [3]. It also reduces the expression of Fc epsilon RI in circulating basophils [9]. The mechanisms by which it reduces the activity of urticaria are not precisely known, but it has been reported to diminish the expression and activation of mast cells of the skin, and the subsequent release of histamine and other mediators such as leukotrienes, tryptase, chymase, prostaglandin D2 and cytokines $[9,10]$.
Omalizumab is approved for the treatment of moderate to severe persistent asthma inadequately controlled with inhaled steroids and positive in vivo or in vitro tests for perennial aero-allergens and achieving improvement of up to $75 \%$ compared to baseline, and now is approved for patients with CIU/CSU [8 ]. Its main adverse effect is anaphylaxis, with a mean frequency of $0,14 \%$ in asthmatic patients that receive the drug [11]; however, side effects reported in patients with CIU/CSU occured in 1-10\% and included local reactions at the injection site (swelling, redness and itching), sinusitis, headache, arthralgia, and upper respiratory infections, with lack of serious and severe adverse events probably due to the lower doses used for this indication $[9,12]$. In some cases there has been a reaction similar to serum sickness. Injection is recommended to be applied at the hospital and followed by an observation period of two hours after the first dose and 30 minutes after subsequent injections.

The effect of omalizumab in CIU/CSU has been measured using the Urticaria Activity Score (UAS), which assesses the number of urticarial lesions and intensity of itching that occurs in one or 7 days, or the Dermatology Life Quality Index (DLQI) which measures the impact of skin diseases on quality of life, among others [10]. Given the above, we decided to conduct a systematic review of the literature where the efficacy of omalizumab is evaluated and compared to placebo, in patients older than 12 years with CIU/CSU in terms of symptom improvement.

\section{Methods}

A systematic literature review was conducted to identify all studies evaluating the efficacy of omalizumab in the treatment of CIU/CSU. The study population included individuals older than 12 years diagnosed with CIU/CSU who had failed to treatment with $\mathrm{H} 1$ antihistamines. The intervention was the use of omalizumab at different doses $(75 \mathrm{mg}, 150 \mathrm{mg}, 300 \mathrm{mg}, 600 \mathrm{mg}$ ) subcutaneously every 4 weeks, and the comparison was to placebo. The main outcome measures were symptom control established by: 1) weekly score of urticarial activity (Urticaria Activity Score -UAS- 7), this being the sum of the individual scores of daily urticaria activity (UAS) in the last 7 days, it can vary from 042 points per week (0 6 days); 2$)$ the weekly Itch Severity Score (Itch Severity Score-ISS-) 
consisting of average daily sum (morning and evening) of pruritus scores in the last 7 days, with 0 being no pruritus, 1 mild, 2 moderate, 3 Severe, with a value from 0 to $21 ; 3$ ) weekly number of wheals measured twice daily (morning and evening) on a scale of 0 when there was no urticaria to 3 when there were over 12 urticaria lesions (0: none, 1 : 1 6, 2: 712 3:> 12 lesions) with a weekly value from 0 to $21 ; 4)$ largest wheal size (0: none, $1:<1.25 \mathrm{~cm}, 2$ : $1.25 \mathrm{~cm}-2.5 \mathrm{~cm}, 3:>2.5 \mathrm{~cm}$ ) twice daily for a week; 5) The Dermatology Life Quality Index, which is a life quality scale that includes 10 items on 6 topics: symptoms and feelings, daily activities, leisure, work/school, personal relationships and treatment. Each item is scored on a 4-point scale ranging from 0 to 3 . The overall score of DLQI ranges from 030 by adding each of the scores of each item. A high score indicates a big change in quality of life; 6) the chronic urticaria quality of life questionnaire (Chronic Urticaria Quality of LifeQuestionnaire$\mathrm{Cu}-\mathrm{Q} 2 \mathrm{LL}-$ ) which includes physical, emotional, social and practical domains that characterize this disease; and 7) presence of angioedema in proportion [13-15]. Safety events were also included such as 8) frequency of adverse events; 9) serious adverse events; and 10) adverse events suspected to be caused by the study drug.

Double-blind placebo-controlled randomized clinical trials (RCTs) were selected. A placebo-controlled randomized clinical trial was defined as a prospective study that included individuals randomly assigned to one or more alternatives including placebo.

A comprehensive and reproducible search for original work was performed in electronic databases related to health PubMed, Medline, Cochrane Central Register of Controlled Trials (CENTRAL), Trip Database, Wiley, Biomed Central, Highwire Press, EBSCO and OVID using MeSH terms, EMTREE terms or keywords that included Omalizumab or Antibodies, Monoclonal, Humanized or placebo and urticaria or angioedema. For the PubMed database we used ( Antibodies, Monoclonal, Humanized [Majr]) OR Placebos [Mesh]) AND ( Urticaria [Mesh] OR Angioedema [Mesh]) [16]. This data search was conducted without language filter and with a date limit to May 31th of 2014, but it was extended to September 30th of 2014 due to a new publication this month. The search was restricted to humans, placebocontrolled RCT. The placebo-controlled RCTs that evaluated the effect of omalizumab on controlling symptoms in patients with chronic idiopathic urticaria were eligible. Other sources of information such as conferences, conference proceedings, posters, newspapers and secondary sources such as systematic reviews, and gray literature were not included. A review by title was performed in the described databases and in those who generated uncertainty, the abstract or the article was revised. Studies unrelated to the question of interest in the title or abstract were excluded and the studies that met the requirements specified for the quality review were included. From the selected articles, we obtained by means of two independent reviewers using a format of data collection, the study reference, work date (year), authors, quality RCT (random sequence, allocation, blinding), eligibility criteria (population, intervention, comparison and outcome, reason for excluding), study design, study duration, number of participants in the intervention group, number of participants in the placebo group, age, sex, country, comorbidities, ethnicity, drug doses, days of treatment, route of administration, side effects, number of patients lost to follow up, outcomes as mean or median differences according to the difference between the baseline measurement and follow-up measurement or percentage change as reported, confidence intervals if included, subgroup analysis if applicable, sources of funding, if they had discrepancies between the two reviewers, a third reviewer assessed the article. A tool provided by the Cochrane Collaboration for assessing the domains of sequence generation, allocation, masking, selective results and other items was used [17]. A format in Excel 2013 for data collection was built and a narrative description of the studies and their characteristics was performed because the differences in interventions (differences in dose and frequency of administration) and in the outcomes were anticipated. Therefore no metaanalysis was considered for publication. The present study had funding from Novartis Pharmaceuticals.

\section{Results}

770 records (Figure 1) were obtained, of these 720 results were excluded when reviewing the title and because of repeated citations, and 18 were excluded when reviewing the abstract. 6 articles were included for final review. Of these 1 was excluded for not meeting inclusion criteria (no randomization) [18]. There were 5 studies left to review quality criteria [19-23]. The assessment of the studies methodological quality is outlined in Table 1 [17]. In general, a low risk of bias was identified in the sequence of random generation among studies, allocation concealment and blinding. There were three studies where there was no blinding of the staff preparing the medication at the center; however, this was not the staff responsible for the administration of the drug [19-23]. In each study the percentage of patients lost was reported. The risk of bias due to patients lost was considered low when it did not exceed $20 \%$. All works, except of Maurer et al., 2011 whom had a $22.7 \%$ lost in the placebo group met this limit (Table 2) [20].

Five studies were included in the systematic review, with a total of 1117 patients with CIU/CSU. The weighted average age was 42.07 years, predominantly of female sex (73\%). Most of participants were Caucasian (85.6\%) taking into account the populations included in these studies 


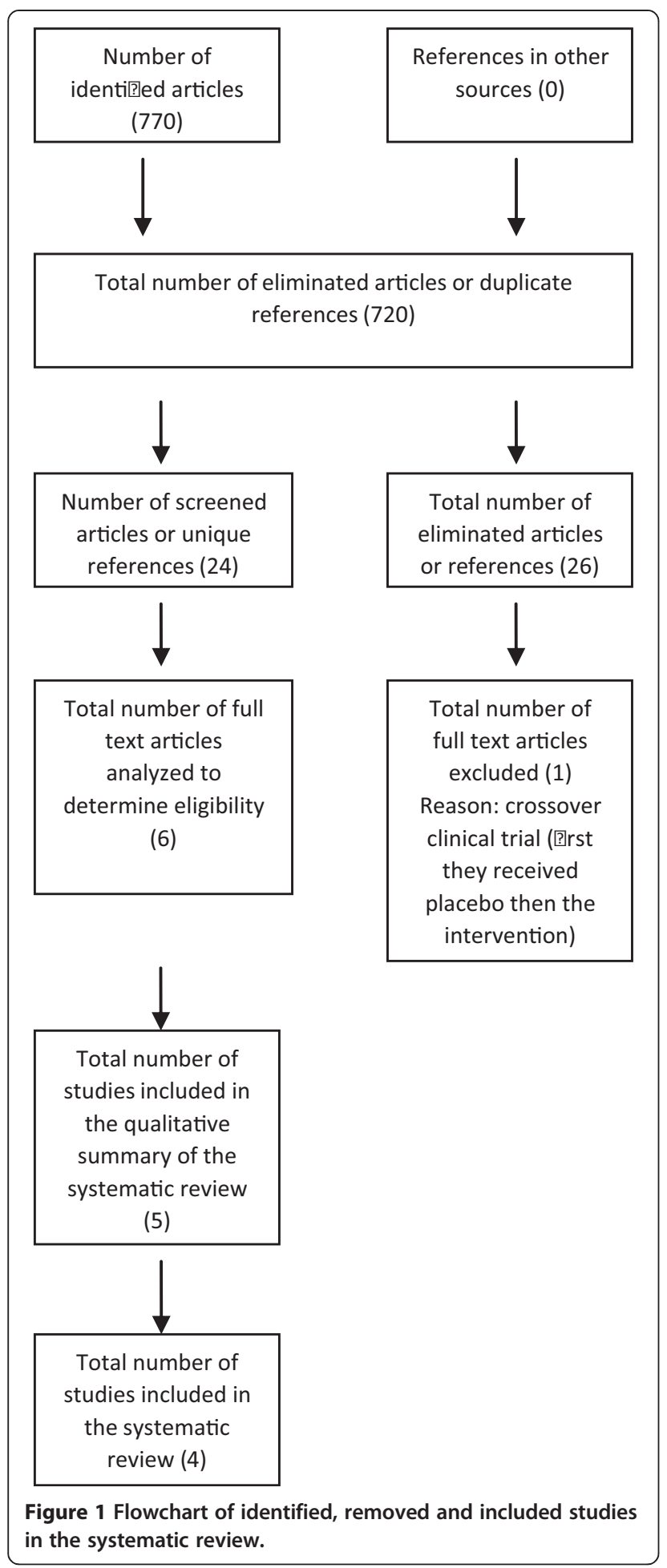

(German and American) although Saini et al., 2013 included patients from Denmark, France, Germany, Italy, Poland, Spain, Turkey and United States (Table 3) [19-23].

Some studies had more than one intervention, comparing different doses of omalizumab vs. placebo every 2 or 4 weeks (75 mg, $150 \mathrm{mg}, 300 \mathrm{mg}$ or $600 \mathrm{mg}$ ) and different follow-up periods (4 24 weeks). In one study, the dose of omalizumab was calculated according to the weight and the levels of immunoglobulin $\mathrm{E}$ (ranging between 75 and $375 \mathrm{mg}$ ) [20]. In Table 2 we describe the study, inclusion criteria, exclusion criteria, sample size, interventions, number of participants included in the intervention and placebo group, time of follow-up and patients lost to follow up or abandonment of treatment.

\section{Effectiveness}

The main outcomes were the change in UAS7 in different periods of follow-up, change in the ISS in the last 7 days from baseline, proportion of patients with UAS7 less or equal to 6 in follow-up periods, change in daily score of urticaria during follow up as well as change in the size score of urticaria (wheal). Outcomes such as the improvement in DLQI and Cu-Q2oL were also included. Safety outcomes such as frequency of at least one adverse event and frequency of adverse events suspected to be caused by the drug were included (Tables 4, 5 and 6).

Maurer et al., reported a significant reduction in UAS7 using omalizumab (75-375 mg every 2 to 4 weeks for 24 weeks) compared with placebo at 24 weeks follow-up (change -17.8 UAS7 in omalizumab , -7.9 in placebo $\mathrm{p}=0.0089$ ) [20]. They reported a smaller area under the curve for UAS in the omalizumab group, compared with placebo $(\mathrm{p}=0.0002)$. They also reported a reduction in urticarial lesions score ( -9.2 vs. -3.3 , respectively, $\mathrm{p}=$ 0.0019 ) and absence of angioedema in $77.8 \%$ of patients, compared with $36.4 \%$ in the placebo group [20].

Saini et al., compared the impact of single doses of omalizumab of $75 \mathrm{mg}, 300 \mathrm{mg}$ and $600 \mathrm{mg}$ vs. placebo, on UAS7 at 4 weeks, with an additional 12 weeks of follow-up to monitor security [21]. They reported significant differences in the dose of $300 \mathrm{mg}$ and $600 \mathrm{mg}$ compared with placebo (300 mg $-19,9$ vs. $-6,9 \mathrm{p}<0,01$; $600 \mathrm{mg}-14,6$ vs. $-6,9 \mathrm{p}=0,047)$. There were also differences in the ISS at week 4 of follow-up between the dose of $300 \mathrm{mg}$ of omalizumab vs. placebo (-9.2 5.98 vs. $-3.55 .22 \mathrm{p}<0.001)$, but not with $75 \mathrm{mg}$ or $600 \mathrm{mg}$ (75 mg $-4.55 .84, \mathrm{p} 0.16,600 \mathrm{mg}-6.55 .63 \mathrm{p}=0.56$ ). Regarding the number of weekly urticarial lesions, a single dose of $300 \mathrm{mg}$ omalizumab lowered this score on average 10.76 .75 , which is significant compared to placebo $(-3.55 .17 \mathrm{p}<0.001)$. The dose of $600 \mathrm{mg}$ also significantly lowered this score $(600 \mathrm{mg}-8,16,0 \mathrm{p}=0,02)$ [21].

Maurer et al., in 2013 reported a randomized double blind clinical trial comparing the use of $75 \mathrm{mg}, 150 \mathrm{mg}$ and $300 \mathrm{mg}$ of omalizumab vs. placebo every 4 weeks for 3 months, followed by 16 weeks of observation [19]. The primary outcome was change in ISS at week 12 compared to baseline, showing significant reductions in mean ISS with doses of $150 \mathrm{mg}$ and $300 \mathrm{mg}$ compared to placebo (150 mg $-8.16 .4300 \mathrm{mg} \quad-9.86 .0$, placebo 


\section{Table 1 Bias evaluation of included studies}

\begin{tabular}{|c|c|c|c|c|c|c|c|}
\hline \multirow[t]{3}{*}{ Study ID } & \multirow[t]{3}{*}{ Author } & \multicolumn{5}{|l|}{ Domains } & \multirow[t]{3}{*}{ Reviewers observations } \\
\hline & & $\begin{array}{l}\text { Random sequence } \\
\text { generation }\end{array}$ & Allocation Blinding & $\begin{array}{l}\text { Participants and people } \\
\text { blinding }\end{array}$ & $\begin{array}{l}\text { Evaluators and } \\
\text { outcome blinding }\end{array}$ & $\begin{array}{l}\text { Incomplete outcome } \\
\text { data }\end{array}$ & \\
\hline & & $\begin{array}{l}\text { Method described with } \\
\text { detail }\end{array}$ & $\begin{array}{l}\text { Investigative personnel was } \\
\text { blind to allocation }\end{array}$ & $\begin{array}{l}\text { Blinding method for } \\
\text { participants and } \\
\text { personnel was } \\
\text { effective? }\end{array}$ & $\begin{array}{l}\text { Blinding method } \\
\text { for the study } \\
\text { evaluators was } \\
\text { effective? }\end{array}$ & $\begin{array}{l}\text { Main outcomes, fall } \\
\text { outs, exclusions, } \\
\text { number, in each } \\
\text { intervention group, } \\
\text { reason for losses and } \\
\text { changes in plan analysis }\end{array}$ & \\
\hline 1 & $\begin{array}{l}\text { Maurer et al., } \\
2011[20]\end{array}$ & $\begin{array}{l}\text { Random sequence by validated } \\
\text { system 1:1 }\end{array}$ & $\begin{array}{l}\text { Similar packages and presentation } \\
\text { between placebo and intervention }\end{array}$ & Yes & Yes & Yes & - \\
\hline 2 & $\begin{array}{l}\text { Saini et al., } \\
2011[21]\end{array}$ & Sequence 1:1:1:1 & $\begin{array}{l}\text { Similar packages and presentation } \\
\text { between placebo and intervention }\end{array}$ & Yes & Yes & Yes & - \\
\hline 3 & $\begin{array}{l}\text { Maurer et al., } \\
2013[19]\end{array}$ & $\begin{array}{l}\text { Sequence 1:1:1:1 by voice } \\
\text { interactive service }\end{array}$ & $\begin{array}{l}\text { Similar packages and presentation } \\
\text { between placebo and intervention }\end{array}$ & Yes & Yes & Yes & $\begin{array}{l}\text { Blind in each center, drug } \\
\text { not blinded but person } \\
\text { administering the drug is } \\
\text { blinded }\end{array}$ \\
\hline 4 & $\begin{array}{l}\text { Kaplan et al., } \\
2013[22]\end{array}$ & $\begin{array}{l}\text { 3:1 stratified by itch severity } \\
\text { score (ISS) and baseline weight }\end{array}$ & $\begin{array}{l}\text { Similar packages and presentation } \\
\text { between placebo and intervention }\end{array}$ & Yes & Yes & Yes & $\begin{array}{l}\text { Person who prepared the } \\
\text { drug was not blinded, but } \\
\text { the one administering the } \\
\text { drug was blinded }\end{array}$ \\
\hline 5 & $\begin{array}{l}\text { Saini et al., } \\
2014[23]\end{array}$ & $\begin{array}{l}\text { Sequence 1:1:1:1 stratified by } \\
\text { weekly ISS, baseline weight } \\
(<\text { or ?80 kg) and study center } \\
\text { by interactive voice and web } \\
\text { response system }\end{array}$ & $\begin{array}{l}\text { Not specified in the article but the } \\
\text { clinicaltrials.gov register specified } \\
\text { the similar packages between } \\
\text { placebo and intervention }\end{array}$ & Yes & Yes & Yes & $\begin{array}{l}\text { Person who prepared the } \\
\text { drug was not blinded but } \\
\text { did not interact with } \\
\text { patients }\end{array}$ \\
\hline
\end{tabular}


Table 2 Inclusion and exclusion criteria, number of eligible randomized studies, sample size, interventions and patients lost from included studies

\begin{tabular}{|c|c|c|c|c|c|c|c|c|c|c|c|}
\hline Study & Author & Author inclusion criteria & Exclusion criteria & Eligible & Randomized & $\begin{array}{l}\text { Sample } \\
\text { Size }\end{array}$ & Interventions & Other treatment received & $\begin{array}{l}\text { Treatment } \\
\text { period }\end{array}$ & $\begin{array}{l}\text { Follow-up } \\
\text { period }\end{array}$ & $\begin{array}{l}\text { Losses } \\
\mathrm{n}(\%)\end{array}$ \\
\hline \multirow[t]{2}{*}{1} & \multirow[t]{2}{*}{$\begin{array}{l}\text { Maurer et al., } \\
2011[20]\end{array}$} & \multirow[t]{2}{*}{$\begin{array}{l}\text { Moderade to severe CSU } \\
\text { with persistent symptoms } \\
\text { for } \geq 6 \text { weeks in spite of } \\
\text { treatment at maximum } \\
\text { doses of antihistamines } \mathrm{H} 1 \text {. } \\
\text { UAS score }>10 \text { at the end } \\
\text { of the test. }\end{array}$} & \multirow{2}{*}{$\begin{array}{l}\text { Acute urticaria, diarrhea, kidney } \\
\text { failure, elevated IgE due to } \\
\text { other allergy or urticaria } \\
\text { reasons, epilepsy, antibiotic } \\
\text { allergic reactions, malignancies } \\
\text { in the last } 5 \text { years, CVA or } \\
\text { ischemia, IV steroid use, } \\
\text { methotrexate, cyclosporine or } \\
\text { other immunosuppressant } \\
4 \text { weeks before }\end{array}$} & \multirow[t]{2}{*}{341} & \multirow[t]{2}{*}{49} & 27 & $\begin{array}{l}27 \text { Omalizumab } \\
75375 \text { mg dose } \\
\text { according to weight, } \\
\text { subcutaneous, once } \\
\text { every } 2 \text { or } 4 \text { weeks } \\
\text { for } 24 \text { weeks }\end{array}$ & \multirow[t]{2}{*}{$\begin{array}{l}\mathrm{H} 1 \text { antihistamines, } 10 \mathrm{mg} \\
\text { of loratadine on demand } \\
\text { and } 1 \mathrm{mg} \text { of clemastine as } \\
\text { rescue medication }\end{array}$} & \multirow[t]{2}{*}{24 weeks } & - & $2(7.40)$ \\
\hline & & & & & & 22 & Placebo & & & - & $5(22.72)$ \\
\hline \multirow[t]{4}{*}{2} & \multirow[t]{4}{*}{$\begin{array}{l}\text { Saini et al., } \\
2011 \text { [21] }\end{array}$} & \multirow{4}{*}{$\begin{array}{l}\text { Idiopathic chronic urticaria, } \\
\text { for more than } 3 \text { months, no } \\
\text { definitive cause, moderate } \\
\text { to severe symptoms, pruritus } \\
\text { and urticaria for more than } \\
3 \text { days in } 7 \text { days for a period } \\
\text { of } 6 \text { weeks in spite of } \\
\text { treatment with antiH1. UAS } \\
\geq 4 \text { or UAS7 } \geq 12 \text { during } \\
\text { run-in period before } \\
\text { randomization. }\end{array}$} & \multirow{4}{*}{$\begin{array}{l}\text { Weight <40 kg, pregnancy or } \\
\text { lactation, other skin disorder } \\
\text { associated to pruritus, } \\
\text { treatment with omalizumab } \\
12 \text { months before, } \\
\text { contraindication for } \\
\text { diphenhydramine, treatment } \\
\text { with any other investigational } \\
\text { rrug } 30 \text { days before, clinically } \\
\text { relevant disease that could } \\
\text { affect the outcomes, } \\
\text { impairment to complete follow } \\
\text { up, use of immunosuppresants } \\
3 \text { months before } \\
\text { hydroxicloroquine, } \\
\text { methotrexate, sulfasalazine, } \\
\text { dapsone, cyclophosphamide, } \\
\text { intravenous immunoglobulin, } \\
\text { plasmapheresis, other therapies } \\
\text { with monoclonal antibodies, } \\
\text { use of cyclosporine in the } \\
\text { month before, use of } \\
\text { antileukotriens or antihistamines } \\
\text { H2 the week before. }\end{array}$} & \multirow[t]{4}{*}{119} & \multirow[t]{4}{*}{90} & 23 & $\begin{array}{l}\text { Omalizumab } 75 \mathrm{mg} \\
\text { single dose sc }\end{array}$ & \multirow{4}{*}{$\begin{array}{l}\text { All patients were provided } \\
25 \mathrm{mg} \text { of diphenhydramine to } \\
\text { use as a rescue medication for } \\
\text { pruritus relief on an as-needed } \\
\text { basis. The maximum allowable } \\
\text { daily dose of diphenhydramine } \\
\text { was } 75 \mathrm{mg} \text { in the United } \\
\text { States and } 50 \mathrm{mg} \text { in Germany. } \\
\text { Patients who required any } \\
\text { other medications(including } \\
\text { systemic corticosteroids) to } \\
\text { treat persistent/worsening } \\
\text { diseasewere discontinued } \\
\text { from the study }\end{array}$} & \multirow[t]{4}{*}{4 weeks } & 12 weeks & $5(21.73)$ \\
\hline & & & & & & 25 & $\begin{array}{l}\text { Omalizumab } 300 \mathrm{mg} \\
\text { single dose sc }\end{array}$ & & & 12 week & $2(8.0)$ \\
\hline & & & & & & 21 & $\begin{array}{l}\text { Omalizumab } 600 \mathrm{mg} \\
\text { single dose sc }\end{array}$ & & & 12 weeks & $1(4.76)$ \\
\hline & & & & & & 21 & Placebo1 & & & 12 weeks & $1(4.76)$ \\
\hline \multirow[t]{4}{*}{3} & \multirow[t]{4}{*}{$\begin{array}{l}\text { Maurer et al., } \\
2013 \text { [19] }\end{array}$} & \multirow{4}{*}{$\begin{array}{l}\text { Idiopathic chronic urticaria } \\
\text { for } 6 \text { months, presence of } \\
\text { urticaria with pruritus for at } \\
\text { least } 8 \text { consecutive weeks } \\
\text { before inclusion in spite of } \\
\text { consecutive use of } \\
\text { antihistamines, UAS } 7 \geq 16 \\
\text { (range } 042 \text { ), weekly itch } \\
\text { score }<=8 \text { (range } 021 \text { ) } 7 \\
\text { days before randomization, } \\
\text { without losses of electronic } \\
\text { poll } 7 \text { days prior to } \\
\text { randomization. }\end{array}$} & \multirow{4}{*}{$\begin{array}{l}\text { Cause of urticaria (physical), } \\
\text { use of systemic glucocorticoids } \\
\text { for } 5 \text { or more days, } \\
\text { hydroxicloroquine, } \\
\text { methotrexate, cyclosporine, } \\
\text { cyclophosphamide, or } \\
\text { intravenous immunoglobulin } \\
30 \text { days before. Use of antiH2 } \\
\text { or leukotriens antagonists days } \\
\text { before the visit ( } 14 \text { days prior } \\
\text { randomization), use of antiH1 } \\
\text { in higher doses than the } \\
\text { allowed } 3 \text { days before the visit, } \\
\text { previous history of cancer, } \\
\text { weight }<20 \mathrm{~kg} \text {, hypersensitivity }\end{array}$} & \multirow[t]{4}{*}{466} & \multirow[t]{4}{*}{323} & 82 & $\begin{array}{l}75 \mathrm{mg} \text { omalizumab, } \\
\text { one injection every } \\
4 \text { weeks for } 3 \text { doses }\end{array}$ & \multirow{4}{*}{$\begin{array}{l}\text { Prerandomization H1- } \\
\text { antihistamine throughout } \\
\text { the treatment period. During } \\
\text { the follow-up period, patients } \\
\text { were permitted to use a } \\
\text { licensed dose of one additional } \\
\mathrm{H} 1 \text {-antihistamine. For the } \\
\text { duration of the study, all } \\
\text { patients were provided with } \\
\text { diphenhydramine ( } 25 \mathrm{mg} \text { ) as } \\
\text { rescue medication for itch relief } \\
\text { (up to a maximum of three } \\
\text { doses in } 24 \text { hours on the basis } \\
\text { of local regulations). }\end{array}$} & \multirow[t]{4}{*}{12 weeks } & 16 weeks & $7(8.53)$ \\
\hline & & & & & & 83 & $\begin{array}{l}150 \text { mg omalizumab, } \\
\text { one injection every } \\
4 \text { weeks for } 3 \text { doses }\end{array}$ & & & 16 weeks & $9(10.84)$ \\
\hline & & & & & & 79 & $\begin{array}{l}300 \mathrm{mg} \text { omalizumab, } \\
\text { one injection every } \\
4 \text { weeks for } 3 \text { doses }\end{array}$ & & & 16 weeks & $\begin{array}{l}12 \\
(15.18)\end{array}$ \\
\hline & & & & & & 79 & $\begin{array}{l}\text { Placebo, similar } \\
\text { presentation to drug }\end{array}$ & & & 16 weeks & $5(6.32)$ \\
\hline
\end{tabular}


Table 2 Inclusion and exclusion criteria, number of eligible randomized studies, sample size, interventions and patients lost from included studies (Continued)

\begin{tabular}{|c|c|c|c|c|c|c|c|c|c|c|c|}
\hline \multirow[t]{2}{*}{4} & \multirow[t]{2}{*}{$\begin{array}{l}\text { Kaplan et al., } \\
2013 \text { [22] }\end{array}$} & \multirow[b]{2}{*}{$\begin{array}{l}12 \text { to } 75 \text { years old, } 1875 \\
\text { years in Germany, idiopathic } \\
\text { chronic urticaria for } 6 \text { months } \\
\text { or more, pruritus and hives for } \\
\text { more than } 6 \text { weeks before } \\
\text { inclusion in spite of antiH1, } \\
\text { antiH2, antileukotriens or both, } \\
\text { UAS7 } \geq 16 \text { and an itchy index } \\
\text { of } 8 \text { or more, } 7 \text { days before } \\
\text { randomization, UAS at the clinic } \\
\text { of } 0 \text { or more in one of the visits, } \\
\text { treatment with antiH1, antiH2, } \\
\text { antileukotriens or both regime, } \\
3 \text { consecutive days, } 14 \text { days } \\
\text { before, patient desires to } \\
\text { participate, signs informed } \\
\text { consent, no loss of symptoms } \\
3 \text { days prior to randomization }\end{array}$} & \multirow{2}{*}{$\begin{array}{l}\text { Cause of urticaria (physical), } \\
\text { daily systemic steroids doses } \\
\text { more than } 5 \text { days, use of } \\
\text { hydroxicloroquine, } \\
\text { methotrexate, cyclosporine, } \\
\text { cyclophosphamide, or } \\
\text { intravenous immunoglobulin } \\
30 \text { days before, previous } \\
\text { history of cancer, } \\
\text { hypersensitivity to omalizumab } \\
\text { in the previous year, evidence } \\
\text { of parasitic infection, history of } \\
\text { anaphylactic shock, pregnancy } \\
\text { or lactation, potential } \\
\text { pregnancy not accepting } \\
\text { contraception }\end{array}$} & \multirow[t]{2}{*}{480} & \multirow[t]{2}{*}{336} & 252 & $\begin{array}{l}\text { Omalizumab } 300 \text { mg } \\
\text { every } 4 \text { weeks for } \\
\text { doses }\end{array}$ & \multirow{2}{*}{$\begin{array}{l}\text { Maintain stable doses of their } \\
\text { prerandomization combination } \\
\text { therapy with } \mathrm{H1} 1 \text {-antihistamine } \\
\text { treatment plus } \mathrm{H} 2- \\
\text { antihistamines, } \mathrm{LTRAs} \text {, or both. } \\
\text { For the duration of the study, } \\
\text { patients were provided with } \\
25 \mathrm{mg} \text { of diphenhydramine as } \\
\text { rescue medication for symptom } \\
\text { relief (up to a maximum of } 3 \\
\text { doses per } 24 \text {-hour period or } \\
\text { fewer depending on local } \\
\text { regulations). }\end{array}$} & \multirow[t]{2}{*}{24 weeks } & 16 weeks & $31(12.3)$ \\
\hline & & & & & & 84 & $\begin{array}{l}\text { Placebo in the same } \\
\text { presentation and } \\
\text { administration }\end{array}$ & & & 16 weeks & $21(25.0)$ \\
\hline \multirow[t]{4}{*}{5} & \multirow[t]{4}{*}{$\begin{array}{l}\text { Saini et al., } \\
2014 \text { [23] }\end{array}$} & \multirow{4}{*}{$\begin{array}{l}12-75 \text { years old, ( } 1875 \text { years } \\
\text { in Germany), with diagnosis } \\
\text { of CSU } \geq 6 \text { months with hives } \\
\text { and itching } \geq 8 \text { consecutive } \\
\text { weeks despite of anti } \mathrm{H} 1 \\
\text { treatment. Use of an approved } \\
\text { dosage of an } \mathrm{H} 1 \text { antihistamine } \\
\text { for } \geq 3 \text { consecutive days, UAS } \\
\geq 4 \text { on one or more screening } \\
\text { days, UAS7 } \geq 16 \text { an itch } \\
\text { component of UAS7 } \geq 8 \\
\text { during the } 7 \text { days before } \\
\text { randomization, willing to } \\
\text { complete symptom diary, no } \\
\text { missing eDiary entries during } \\
\text { the } 7 \text { days before } \\
\text { randomization }\end{array}$} & \multirow{4}{*}{$\begin{array}{l}\text { Clearly defined underlying } \\
\text { etiology for chronic urticaria } \\
\text { (cold, presure, etc.), presence } \\
\text { of disease with symptoms of } \\
\text { urticaria or angioedema, } \\
\text { including hereditary or } \\
\text { acquired angioedema, routine } \\
\text { dosis of systemic steroids, } \\
\text { hydroxychloroquine, } \\
\text { methotrexate, cyclosporine, } \\
\text { cyclophosphamide, or } \\
\text { intravenous immunoglobulin } \\
\leq 30 \text { days of day }-14 \text {. use of } \\
\text { H2-antihistamines or LTRA } \\
\leq 7 \text { days of day }-14 \text {. use of H1 } \\
\text { antihistamines at greater than } \\
\text { the approved doses } \leq 3 \text { days of } \\
\text { day }-14 \text {. history of malignancy, } \\
\text { weight }<20 \text { kg, hypersensitivity } \\
\text { to omalizumab, previous } \\
\text { treatment with omalizumab } \\
\text { within the previous year. }\end{array}$} & \multirow[t]{4}{*}{483} & \multirow[t]{4}{*}{319} & 78 & $\begin{array}{l}\text { Omalizumab } 75 \text { mg } \\
\text { every } 4 \text { weeks for } 6 \\
\text { doses }\end{array}$ & \multirow{4}{*}{$\begin{array}{l}\text { Maintain stable doses of } \\
\text { their prerandomization } \mathrm{H} 1 \\
\text { antihistamine treatment. } \\
\text { Weeks } 13 \text { to } 24 \text { patients were } \\
\text { allowed to add one additional } \\
\mathrm{H} 1 \text { antihistamine. Patients } \\
\text { were permitted to take } \\
\text { diphenhydramine } 25 \mathrm{mg} \text { as } \\
\text { needed for itch relief (up to a } \\
\text { maximum of three doses per } \\
24 \text { hours, or less if required by } \\
\text { local regulations) }\end{array}$} & \multirow[t]{4}{*}{24 weeks } & 16 weeks & $\begin{array}{l}11 \\
(14.10)\end{array}$ \\
\hline & & & & & & 80 & $\begin{array}{l}\text { omalizumab } 150 \mathrm{mg} \\
\text { every } 4 \text { weeks for } 6 \\
\text { doses }\end{array}$ & & & 16 weeks & $16(20.0)$ \\
\hline & & & & & & 81 & $\begin{array}{l}\text { omalizumab } 300 \mathrm{mg} \\
\text { every } 4 \text { weeks por } 6 \\
\text { doses }\end{array}$ & & & 16 weeks & $8(9.87)$ \\
\hline & & & & & & 80 & placebo & & & 16 weeks & $\begin{array}{l}19 \\
(23.75)\end{array}$ \\
\hline
\end{tabular}


Table 3 Demographic characteristics and mean weight and IgE of patients in the included studies

\begin{tabular}{|c|c|c|c|c|c|c|c|c|}
\hline Study ID & Interventions & Age (mean ? SD) & $\begin{array}{l}\text { Female sex } \\
\mathrm{n}(\%)\end{array}$ & $\begin{array}{l}\text { Caucasian } \\
\mathrm{n}(\%)\end{array}$ & $\begin{array}{l}\text { Weight }(\mathbf{k g}) \\
\text { mean? SD }\end{array}$ & $\begin{array}{l}<80 \mathrm{~kg} \\
\mathrm{n}(\%)\end{array}$ & $\begin{array}{l}\mathrm{IgE}(\mathrm{IU} / \mathrm{mL}) \\
\text { mean ? SD }\end{array}$ & $\begin{array}{l}\operatorname{lgE}(\mathrm{IU} / \mathrm{mL}) \\
\text { median (range) }\end{array}$ \\
\hline \multirow[t]{2}{*}{1} & Omalizumab 75-375 & $39.1 ? 9.0$ & 19 (70.4) & $27(100.0)$ & $81.9 ? 20.2$ & - & $211 ? 158$ & - \\
\hline & Placebo & $42.3 ? 15.0$ & $19(86.4)$ & $22(100.0)$ & $71.2 ? 12.4$ & - & $181 ? 136$ & - \\
\hline \multirow[t]{4}{*}{2} & Omalizumab 75 & $38.8 ? 15.5$ & $15(65.2)$ & $20(87.0)$ & $80.5 ? 21.6$ & $14(60.9)$ & $251.5 ? 389.6$ & 1500) \\
\hline & Omalizumab 300 & $42.9 ? 15.7$ & $17(68.0)$ & $19(76.0)$ & $82.2 ? 22.8$ & $13(52.0)$ & $170.5 ? 178.5$ & $131.5(2$ \\
\hline & Omalizumab 600 & $40 ? 11.1$ & $12(57.1)$ & $18(85.7)$ & $80.6 ? 18.1$ & $11(52.4)$ & $134.9 ? 142.9$ & $90(4$ \\
\hline & Placebo & $41.2 ? 16.2$ & $17(81)$ & $18(85.7)$ & $80.4 ? 24.8$ & $13(61.9)$ & $297.4 ? 748.9$ & 1500) \\
\hline \multirow[t]{4}{*}{3} & Omalizumab 75 & $39.7 ? 15.0$ & $61(74.0)$ & $64(78.0)$ & $82.8 ? 21.2$ & $43(52.4)$ & $168.2 ? 321.9^{* *}$ & 79 \\
\hline & Omalizumab 150 & $43.0 ? 13.2$ & $65(79.0)$ & $70(85.0)$ & $82.4 ? 20.7$ & $41(49.4)$ & - & - \\
\hline & Omalizumab 300 & $44.3 ? 13.7$ & $63(80.0)$ & $68(86.0)$ & $80.3 ? 19.9$ & $41(51.9)$ & - & - \\
\hline & Placebo & $43.1 ? 12.5$ & $55(70.0)$ & $70(89.0)$ & $84.3 ? 25.7$ & $41(51.9)$ & - & - \\
\hline \multirow[t]{2}{*}{4} & Omalizumab 300 & $42.7 ? 17.9$ & $186(73.8)$ & $223(88.5)$ & $29.4 ? 7.1^{*}$ & - & $162.3 ? 306.4$ & 3050) \\
\hline & Placebo & $44.3 ? 14.7$ & $55(66.3)$ & $75(90.4)$ & $31 ? 9.6^{*}$ & - & $147.2 ? 224.4$ & 1230) \\
\hline \multirow[t]{4}{*}{5} & Omalizumab 75 & $40.7 ? 15.2$ & $55(71.4)$ & $62(80.5)$ & $81.1 ? 19.2$ & $38(48.7)$ & - & $91\left(\begin{array}{ll}1 & 2030\end{array}\right)$ \\
\hline & Omalizumab 150 & $41.1 ? 14$ & $64(80.0)$ & $63(78.8)$ & $83.2 ? 24.4$ & $40(50.0)$ & - & $71(1 \quad 5000)$ \\
\hline & Omalizumab 300 & $42.4 ? 13.2$ & $60(74.1)$ & 74 (91.4) & $81.6 ? 19.7$ & $45(55.5)$ & - & $85.5\left(\begin{array}{ll}1 & 2330\end{array}\right)$ \\
\hline & Placebo & $40.4 ? 15.6$ & $52(65.0)$ & $64(80.0)$ & $83 ? 20.5$ & 35 (43.7) & - & $92\left(\begin{array}{ll}1 & 1010\end{array}\right)$ \\
\hline
\end{tabular}

*BMI (kg/m2). **mean and SD of all patients included. SD: standard deviation. IgE: Immunoglobulin E normal range 13 to $127 \mathrm{IU} / \mathrm{mL}$.

$-5.15 .6 \mathrm{p}<0.01 \mathrm{y}<0.001$ respectively). Similar behavior was also observed in the number of urticarial lesions at week 12 , the percentage of patients with UAS7 $\leq 6$, and the rate of dermatology life quality at week 12 , but not with the dose of $75 \mathrm{mg}$ (Tables 4 and 5). There was also a higher rate of angioedema-free days in the group receiving $300 \mathrm{mg}$ of omalizumab compared to placebo (95.5\% vs. $89.2 \%$ p <0.001), a difference that was not observed with doses of 150 or $75 \mathrm{mg}$ (91.6\% and $93.5 \%$ respectively) [19].

Kaplan et al. in 2013, compared the dose of $300 \mathrm{mg}$ of omalizumab every 4 weeks for 6 months vs. placebo in

Table 4 Description of urticaria activity score, weekly itch severity score, and the magnitude of change before and after treatment

\begin{tabular}{|c|c|c|c|c|c|c|c|}
\hline Study ID & Sample size & Intervention & $\begin{array}{l}\text { UAS7 baseline } \\
\text { (mean? SD) }\end{array}$ & $\begin{array}{l}\text { Change in UAS7 } \\
\text { (mean? SD) }\end{array}$ & $\begin{array}{l}\text { UAS }<6 \\
\text { n (\%) }\end{array}$ & $\begin{array}{l}\text { ISS baseline } \\
\text { (mean? SD) }\end{array}$ & $\begin{array}{l}\text { Change in weekly } \\
\text { ISS (mean? SD }\end{array}$ \\
\hline \multirow[t]{2}{*}{1} & 27 & Omalizumab 75-375 mg & $24.6 ? 7.4$ & $-17.8^{\dagger}$ & - & - & - \\
\hline & 22 & Placebo & $21.3 ? 7.6$ & -7.9 & - & - & - \\
\hline \multirow[t]{4}{*}{2} & 23 & Omalizumab 75 mg & $27.3 ? 8.31$ & $-9.8 ? 11.75$ & - & $13.1 ? 3.53$ & $-4.5 ? 5.84$ \\
\hline & 25 & Omalizumab 300 mg & $27.3 ? 7.19$ & $-19.9 ? 12.38^{\dagger}$ & - & $13 ? 3.72$ & $-9.2 ? 5.98^{\dagger}$ \\
\hline & 21 & Omalizumab 600 mg & $26.8 ? 6.98$ & $-14.6 ? 10.17$ & - & $12.6 ? 3.19$ & $-6.5 ? 5.63$ \\
\hline & 21 & Placebo & $31 ? 7.32$ & $-69 ? 9.84$ & - & $14 ? 4.23$ & $-3.5 ? 5.22$ \\
\hline \multirow[t]{4}{*}{3} & 82 & 75 mg omalizumab & $30.7 ? 6.9$ & - & $22(27)$ & $14 ? 3.7$ & $-5.9 ? 6.5$ \\
\hline & 83 & 150 mg omalizumab & $31.4 ? 7.0$ & - & $35(43)^{\top}$ & $14.2 ? 4.1$ & $-8.1 ? 6.4^{\dagger}$ \\
\hline & 79 & 300 mg omalizumab & $29.5 ? 6.9$ & - & $52(66)^{+}$ & $13.7 ? 3.5$ & $-9.8 ? 6.0^{\dagger}$ \\
\hline & 79 & Placebo & $31 ? 6.6$ & - & $15(19)$ & $14 ? 3.4$ & $-5.1 ? 5.6$ \\
\hline \multirow[t]{2}{*}{4} & 252 & Omalizumab 300 mg & $31.2 ? 6.6$ & $-19(20.6 a-17.4)^{*^{\dagger}}$ & $132(52)^{\dagger}$ & $14 ? 3.6$ & $-8.6(-9.3 a-7.8)^{*}{ }^{\top}$ \\
\hline & 84 & Placebo & $30.2 ? 6.7$ & $-8.5(-11.1 a-5.9)^{* \top}$ & $10(12)$ & $13.8 ? 3.6$ & $-4.0(-5.3 a-2.7)^{*}$ \\
\hline \multirow[t]{4}{*}{5} & 78 & Omalizumab 75 mg & $31.7 ? 6.7$ & $-13.82 ? 13.26^{\top}$ & $20(26)$ & $14.5 ? 3.6$ & $-6.46 ? 6.14^{+}$ \\
\hline & 80 & Omalizumab 150 mg & $30.3 ? 7.3$ & $-14.44 ? 12.95^{\top}$ & $32(40)$ & $14.1 ? 3.8$ & $-6.66 ? 6.28^{\top}$ \\
\hline & 81 & Omalizumab 300 mg & $31.3 ? 5.8$ & $-20.75 ? 12.17^{\top}$ & $42(52)$ & $14.2 ? 3.3$ & $-9.4 ? 5.73^{\dagger}$ \\
\hline & 80 & Placebo & $31.1 ? 6.7$ & $-8.01 ? 11.47$ & $9(11)$ & $14.4 ? 3.5$ & $-3.63 ? 5.22$ \\
\hline
\end{tabular}

UAS7: Urticaria Activity Index in 7 days, ISS: Itch Severity Score, SD: standard deviation, ${ }^{*}$ mean and $95 \%$ confidence interval, ${ }^{\top} p<0.01$ compared to placebo. 
Table 5 Description weekly urticarial score, DLQI, Cu-Q2oL, presence of angioedema at baseline and change by intervention administered

\begin{tabular}{|c|c|c|c|c|c|c|c|c|c|}
\hline $\begin{array}{l}\text { Study } \\
\text { ID }\end{array}$ & $\begin{array}{l}\text { Sample } \\
\text { size }\end{array}$ & Intervention & $\begin{array}{l}\text { Weekly urticaria } \\
\text { score at baseline }\end{array}$ & $\begin{array}{l}\text { Change in weekly urticaria } \\
\text { score (mean? SD) }\end{array}$ & $\begin{array}{l}\text { DLQI baseline } \\
\text { (mean ? SD) }\end{array}$ & $\begin{array}{l}\text { Change in DLQI } \\
\text { (mean? SD) }\end{array}$ & $\begin{array}{l}\text { Cu-Q2oL } \\
\text { improvement (\%) }\end{array}$ & $\begin{array}{l}\text { Presence of angioedema } \\
\text { baseline, } n(\%)\end{array}$ & $\begin{array}{l}\text { Angioedema } \\
\text { free days (\%) }\end{array}$ \\
\hline \multirow[t]{2}{*}{1} & 27 & Omalizumab 75-375 mg & - & $-9,2^{\dagger}$ & - & $62,4^{*}$ & 50 & - & 77,8 \\
\hline & 22 & Placebo & - & $-3,3$ & - & $15,3^{*}$ & 6,3 & - & 36,4 \\
\hline \multirow[t]{4}{*}{2} & 23 & Omalizumab 75 mg & $14,2 ? 5,71$ & $-5,3 ? 6,91$ & - & - & - & - & - \\
\hline & 25 & Omalizumab 300 mg & $14,7 ? 4,62$ & $-10,7 ? 6,75^{\dagger}$ & - & - & - & - & - \\
\hline & 21 & Omalizumab 600 mg & $14,2 ? 4,81$ & $-8,1 ? 6,0$ & - & - & - & - & - \\
\hline & 21 & Placebo & $17 ? 4,79$ & $-3,5 ? 5,17$ & - & - & - & - & - \\
\hline \multirow[t]{4}{*}{3} & 82 & 75 mg omalizumab & $16,8 ? 4,2$ & $-7,2 ? 7,0$ & $12,6 ? 6,5$ & $-7,5 ? 7,2$ & - & $31(38)$ & 93,5 \\
\hline & 83 & 150 mg omalizumab & $17,1 ? 4,1$ & $-9,8 ? 7,3^{\top}$ & $13 ? 6,1$ & $-8,3 ? 6,3$ & - & $38(46)$ & 91,6 \\
\hline & 79 & 300 mg omalizumab & $15,8 ? 4,6$ & $-12,0 ? 7,6^{\dagger}$ & $12,7 ? 6,4$ & $-10,2 ? 6,8^{+}$ & - & $32(41)$ & 95,5 \\
\hline & 79 & placebo & $17 ? 4,2$ & $-5,2 ? 6,6$ & $12,6 ? 5,9$ & $-6,1 ? 7,5$ & - & $30(38)$ & $89,2^{\top}$ \\
\hline \multirow[t]{2}{*}{4} & 252 & Omalizumab 300 mg & $17,1 ? 4,2$ & $-10,5(-11,4 a-9,5)^{* \top}$ & - & $-9,7(-10,6 a-8,8)^{* \top}$ & $-3,9(-4,9 a-3,0)^{* \top}$ & $137(54,4)$ & $91^{\dagger}$ \\
\hline & 94 & Placebo & $16,4 ? 4,6$ & $-4,5(-5,9 a-3,1)^{*}$ & - & $-5,1(-7,0 a-3,2)^{*}$ & $-2,7(-3,8 a-1,6)^{*}$ & $41(49,4)$ & 88,1 \\
\hline \multirow[t]{4}{*}{5} & 78 & Omalizumab 75 mg & $17,2 ? 4,2$ & & $12,8 ? 6,1$ & & & $35(45,5)$ & \\
\hline & 80 & Omalizumab 150 mg & $16,2 ? 4,6$ & & $13,6 ? 7,1$ & & & $38(47,5)$ & \\
\hline & 81 & Omalizumab 300 mg & $17,1 ? 3,8$ & & $13,0 ? 6,7$ & $10,29(7,3)$ & & $34(42,0)$ & 96,1 \\
\hline & 80 & Placebo & $16,7 ? 4,4$ & & $14,0 ? 6,6$ & $6,13(5,25)$ & & $44(55,0)$ & 88,2 \\
\hline
\end{tabular}

SD: standard deviation, DLQl: Dermatologic Life Quality Intex, Cu-Q2oL: Chronic urticaria Quality of Life Questionnaire, ${ }^{*}$ mean and $95 \%$ confidence interval, ${ }^{\top} \mathrm{p}<0.01$ compared to placebo. 
Table 6 Adverse events reported in the included studies

\begin{tabular}{|c|c|c|c|c|c|c|}
\hline Study ID & Sample size & Intervention & $\begin{array}{l}\text { At least } 1 \text { adverse } \\
\text { event } n(\%)\end{array}$ & $\begin{array}{l}\text { Adverse event during } \\
\text { follow up, } n(\%)\end{array}$ & $\begin{array}{l}\text { Event allegedly } \\
\text { caused drug } \mathrm{n}(\%)\end{array}$ & $\begin{array}{l}\text { Serious adverse } \\
\text { event } n(\%)\end{array}$ \\
\hline \multirow[t]{2}{*}{1} & 27 & Omalizumab 75-375 mg & $22(81.5)$ & - & $6(22.2)$ & - \\
\hline & 22 & Placebo & $19(86.4)$ & - & $6(22.7)$ & - \\
\hline \multirow[t]{4}{*}{2} & 23 & Omalizumab 75 mg & $8(34.8)$ & $9(50.0)$ & - & - \\
\hline & 25 & Omalizumab 300 mg & $12(48.0)$ & $12(52.2)$ & - & - \\
\hline & 21 & Omalizumab 600 mg & $10(47.6)$ & $5(25.0)$ & - & - \\
\hline & 21 & Placebo & $10(47.6)$ & $7(35.0)$ & - & - \\
\hline \multirow[t]{4}{*}{3} & 82 & 75 mg omalizumab & $45(59)$ & - & $7(9)$ & $4(5)$ \\
\hline & 83 & 150 mg omalizumab & $59(67)$ & - & $8(9)$ & $5(6)$ \\
\hline & 79 & 300 mg omalizumab & $51(65)$ & - & $7(9)$ & $6(8)$ \\
\hline & 79 & placebo & $48(61)$ & - & $3(4)$ & $7(9)$ \\
\hline \multirow[t]{2}{*}{4} & 252 & Omalizumab 300 mg & $211(83.7)$ & - & $28(11.1)$ & $18(7.1)$ \\
\hline & 84 & Placebo & $65(78.3)$ & - & $11(13.3)$ & $5(6)$ \\
\hline \multirow[t]{4}{*}{5} & 78 & Omalizumab 75 mg & 55 (78.6) & $36(51.4)$ & $6(8.6)$ & $2(2.9)$ \\
\hline & 80 & Omalizumab 150 mg & $72(82.8)$ & $45(51.7)$ & $9(10.3)$ & $5(5.7)$ \\
\hline & 81 & Omalizumab 300 mg & $57(70.4)$ & $38(46.9)$ & $14(17.3)$ & $2(2.5)$ \\
\hline & 80 & Placebo & $53(66.3)$ & $32(40.0)$ & $4(5.0)$ & $5(6.3)$ \\
\hline
\end{tabular}

the treatment of CIU/CSU, including other treatment options such as $\mathrm{H} 2$ antihistamines and leukotriene modifiers [22]. They found a significant change at week 12 in the ISS ( $-8.695 \% \mathrm{CI}-9.3$ to -7.8 vs. $-4.095 \% \mathrm{CI}-5.3$ to -2.7 respectively, $\mathrm{p}<0.001)$, in the UAS7 $(-1995 \% \mathrm{CI}-20.6$ to -17.4 vs. $-8.5,95 \% \mathrm{CI}-11.1$ to $-5.9 \mathrm{p}<0.001)$, in the weekly score of urticarial lesions (- $10.595 \%$ CI -11.4 to -9.5 vs. $-4.595 \% \mathrm{CI}-5.9$ to $-3.1 \mathrm{p}<0.001)$ in the DLQI $(-9.795 \%$ CI -10.6 to -8.8 vs. $-5.195 \%$ CI -7.0 to $-3.2 \mathrm{p}<0.001)$, and the percentage of days free of angioedema (95\% CI 91882 to 93.8 vs. 88.1 95\% CI 83.6 to $92.7 \mathrm{p}<0.001$ ) (Tables 4 and 5) [22].

Saini et al. in 2014, compared the dose $75 \mathrm{mg}, 150 \mathrm{mg}$, and $300 \mathrm{mg}$ every 4 weeks for 6 months vs placebo in patients with CIU/CSU, despite the use of H1-antihistamine. They reported a statistical improvement in UAS7 (mean change -13.82 in $75 \mathrm{mg},-14.4$ in $150 \mathrm{mg},-20.75$ in $300 \mathrm{mg}$ vs -8.01 in placebo), ISS (mean change -6.46 in $75 \mathrm{mg},-6.66$ in $150 \mathrm{mg},-9.4 \mathrm{in} 300 \mathrm{mg}$ vs 3.63 in placebo) and angioedema free days $96.1 \%$ in $300 \mathrm{mg}$ vs $88.2 \%$ in placebo (Tables 4 and 5) [23].

After the end of treatment period, three studies reported the recurrence of symptoms in terms of ISS and weekly score of hives. Maurer et al. 2013 reported statistical significant differences between $300 \mathrm{mg}$ of omalizumab and placebo at week 18 (six weeks after ending the treatment) being similar to placebo after 18 week. Also, $300 \mathrm{mg}$ of omalizumab reduced the weekly score of hives at week 18 comparted to placebo [19]. Kaplan et al. 2013 reported during the follow-up period significant differences between omalizumab $300 \mathrm{mg}$ and placebo at 33 week in the ISS score. These gradually increased to values similar to those in the placebo group after the 33 week, there were no statistical differences between omalizumab and placebo groups at week 40 [22]. Saini et al. 2014 reported after 24 week, the ISS difference of omalizumab $300 \mathrm{mg}$ compared to placebo maintained to the 31 week, the ISS increased to values similar to those in the placebo group and at the end of the follow up there were no differences between omalizumab and placebo groups [23].

There are also multiple case series and uncontrolled studies reporting the benefit of this drug in the treatment of chronic idiopathic urticaria (Table 7).

\section{Safety}

Maurer et al. in 2011, reported a similar incidence of adverse events suspected to be caused by omalizumab and placebo (22.2\% and $22.7 \%$ respectively), with no clinical evidence or any trends in laboratory parameters that were associated with treatment with omalizumab [20]. They reported $44 \%$ of adverse events during the treatment period (day 0 to week 4) (placebo $47.6 \%$, omalizumab $75 \mathrm{mg} 34.8 \%, 300 \mathrm{mg} \mathrm{48 \%}$ and $600 \mathrm{mg}$ 47.6\%) [21]. Adverse events requiring priority treatment greater than 5\% were: upper respiratory tract infection, headache, nasopharyngitis, and dysmenorrhea. During follow-up (week 4 16), 40.7\% of patients experienced at least one adverse event (35\% placebo, $75 \mathrm{mg}$ omalizumab: $50 \%$, $300 \mathrm{mg}$ : 52.2\%, $600 \mathrm{mg}$ : 25\%). $4.4 \%$ of participants had an adverse event that led to discontinuation of treatment (pregnancy, asthma, 
Table 7 Summary of non-controlled studies and outcomes

\begin{tabular}{|c|c|c|c|c|c|}
\hline \multicolumn{6}{|c|}{ Effects of omalizumab in patients with urticaria: uncontrolled studies } \\
\hline Author (year) & Urticary type & $\mathbf{N}$ & No response & Partial response & Complete response \\
\hline Ivyanskiy (2012) & CIU 12, AIU 6, DPU 1 & 19 & 3 & 5 & 11 \\
\hline Ferrer (2011) & CSU & 9 & 2 & 5 & 2 \\
\hline Groffik (2011) & CSU & 9 & 0 & 4 & 5 \\
\hline S?nchez-Mach?n (2011) & CSU & 1 & 0 & 0 & 1 \\
\hline Saavedra (2011) & CSU & 1 & 0 & 0 & 1 \\
\hline Krause (2010) & Dermographic U & 1 & 0 & 0 & 1 \\
\hline Buller Kotte (2010) & Heat U & 1 & 0 & 0 & 1 \\
\hline Binslej-Jensen(2010) & DPU & 1 & 0 & 0 & 1 \\
\hline Magerl (2010) & CSU & 8 & 0 & 1 & 7 \\
\hline Al-Ahmad (2010) & AlU & 3 & 0 & 0 & 3 \\
\hline Kemoli (2010) & AlU & 1 & 0 & 0 & 1 \\
\hline Sabroe (2010) & Cholinergic U & 1 & 1 & 0 & 0 \\
\hline Waiber (2009) & Solar U & 1 & 0 & 1 & 0 \\
\hline Maspero (2009) & AlU & 1 & 0 & 0 & 1 \\
\hline Kaplan (2008) & AlU & 12 & 1 & 4 & 7 \\
\hline G?zelbey (2008) & Solar U & 1 & 0 & 0 & 1 \\
\hline Metz (2008) & Cholinergic U & 1 & 0 & 0 & 1 \\
\hline Godse (2008) & CSU & 3 & 0 & 0 & 3 \\
\hline Sands (2007) & $C A U$ & 3 & 0 & 0 & 3 \\
\hline Spector (2007) & $2 \mathrm{AIU}, 1 \mathrm{CSU}$ & 3 & 0 & 0 & 3 \\
\hline TOTAL & & 78 & $7(8,9 \%)$ & $20(25,6 \%)$ & $51(65,3 \%)$ \\
\hline
\end{tabular}

CIU: Chronic Idiopathic Urticaria; AIU: Aspirin induced Urticaria; DPU: Delayed Pressure Urticaria; CSU: Chronic Spontaneous Urticaria; CAU: Chronic Autoinmune Urticaria.

itching -Dose $75 \mathrm{mg}-$, exacerbation of urticaria -Dose $600 \mathrm{mg}-)$ [20].

Maurer et al. in 2013 reported 59\%, 67\% and 65\% of adverse events at doses of 75, 150 and $300 \mathrm{mg}$ of omalizumab, respectively, compared to $61 \%$ in the placebo group [19]. Nine serious adverse events were reported, of which 5 were in the group receiving $300 \mathrm{mg}$ of omalizumab, two in the placebo group, one in the group receiving $75 \mathrm{mg}$ and one in the group receiving $150 \mathrm{mg}$. Most events were reported during study phases where patients were not receiving active treatment.

Kaplan et al. reported an $83.7 \%$ frequency of one or more adverse events in the group receiving $300 \mathrm{mg}$ of omalizumab for 16 weeks and $78.3 \%$ of adverse events in the placebo group [22]. Of these, a relation with the intervention was suspected in $11.1 \%$ and $13.5 \%$ respectively, and $7.1 \%$ and $6.0 \%$ were considered serious adverse events respectively. Adverse events requiring priority treatment were mainly gastrointestinal effects (nausea, diarrhea, abdominal pain), and presented at similar frequency in both groups. During the treatment period, $65.1 \%$ of adverse events occurred in omalizumab-treated patients vs. $63.9 \%$ in the placebo group, the most common being headache and upper respiratory tract infections in the omalizumab group and nasal congestion, migraine and idiopathic urticaria in the placebo group. In the follow-up period, the incidence of adverse events was similar in both groups $(52 \%$ vs. $47 \%$ respectively). There was $2.8 \%$ of serious adverse events with omalizumab and $3.6 \%$ with placebo. No serious adverse events related to treatment were reported in this study.

Saini et al. 2014 reported any adverse event in $300 \mathrm{mg}$ of omalizumab $70.4 \%, 82.8 \%$ in $150 \mathrm{mg}, 78.6 \%$ in $75 \mathrm{mg}$ and $66.3 \%$ in the placebo group. The most common symptoms were headaches, arthralgia and injection-site reactions in omalizumab group as compared with placebo. The proportion of patients with adverse events reported as suspected to be cause by the study drug increased as the dose of omalizumab increased. There were 2 severe events in $150 \mathrm{mg}$ and $300 \mathrm{mg}$ groups. In this study three patients had suspected anaphylaxis, two of them during omalizumab treatment and one 142 days post final dose of study drug althought the anaphylaxis was not attributed to study drug [23].

\section{Discussion}

Although CIU/CSU is a disease with a low probability of death, it has a high impact on the quality of life of 
affected individuals. The therapeutic options available, mainly $\mathrm{H} 1$ antihistamines and anti-leukotrienes may not be sufficient to achieve adequate control of symptoms [8]. In this subgroup of patients in whom the use of immunosuppressive agents is indicated as an alternative, the use of omalizumab for the treatment of CIU/CSU has been proposed $[3,8,18]$. Although little information is yet available about this drug, its safety has been demonstrated in patients with asthma. This is the first systematic review of omalizumab in chronic idiopathic urticaria reported in the literature. Of 1117 patients obtained, 831 received at least one dose of omalizumab in randomized controlled clinical trials with placebo. There are also multiple case series and uncontrolled studies reporting the benefit of this drug in the treatment of various types of CU.

The different doses used in the studies show a clear benefit of using omalizumab $300 \mathrm{mg}$ compared with placebo in the treatment of the disease. One of the most important limitations was the use of different doses across studies, time of management, and follow-up of results, which ranged from single dose to monthly doses for 24 weeks. However, three studies evaluated the dose of $300 \mathrm{mg}$ that resulted in improvement of UAS7, ISS and urticaria score compared with placebo. Another important limitation was the quantitative score of change in the different scales, from a categorical scale of severity of symptoms, making it difficult to perform a clinical interpretation of the reduction in the average of each of the scales. However, the authors reported a significant minimum difference, and also on these scales, the score of 0 means no symptoms and the maximum score a greater intensity of symptoms. The main strength of the studies was that they were randomized clinical trials with adequate methodology and low loss of patients during follow-up.

With the above, although no meta-analysis was performed by differences in the dose and times of treatment, it can be concluded that the dose of $300 \mathrm{mg}$ of omalizumab appears to be effective in treating CIU/CSU, but it is associated with a higher frequency of adverse effects (headache and upper respiratory infection). Further studies evaluating the efficacy of the dose of $300 \mathrm{mg}$ of omalizumab in different population groups are needed, since the reported studies included patients from Germany and the United States mainly. The duration of effective treatment with fewer incidence of adverse events must also be determined.

\section{Competing interest}

The present study has been sponsored by Novartis. DCC and CS have received a grant for the elaboration of the manuscript.

\section{Authors contributions}

DCC: participated in the design of the study and performed the statistical an?lisis EG: conceived of the study and participated in the design EE: participated in its design and helped to draft the manuscript MSB: participated in its design and helped to draft the manuscript CDS: conceived of the study and participated in its design and coordination and helped to draft the manuscript. All authors read and approved the final manuscript.

\section{Authors information}

DCC: Specialist in Internal Medicine and Epidemiology. Fundaci?n Valle del Lili. Cali, Colombia EG: Specialist in Allergy and Clinical Immunology. Chief of Allergy Unit. Fundaci?n Santa F? de Bogot?. Bogot?, Colombia EE: Specialist in Internal Medicine and Allergology. Proffesor Universidad del Norte. Barranquilla, Colombia. MSB: Specialist in Allergy and Clinical Immunology. Centro M?dico-Docente La Trinidad. Caracas, Venezuela. CDS: Specialist in Internal Medicine and Allergology. Chief of Allergy Unit. Fundaci?n Valle del Lili. Cali, Colombia

\section{Author details}

'Department of Internal Medicine, Fundaci?n Valle del Lili, Carrera 98 \# 18-49, Cali, Colombia. ${ }^{2}$ Allergy and Clinical Immunology Department, Centro M?dico-Docente La Trinidad, Avenida Intercomunal La Trinidad, El Hatillo, Apartado Postal 80474, 1080-A Caracas, Venezuela. ${ }^{3}$ Allergy Unit, Fundaci?n Santa F? de Bogot?, Carrera 7B \# 123-90, Bogot?, Colombia. ${ }^{4}$ Medicine Department. Universidad del Norte, Kilometro 5 v?a a Puerto Colombia, Barranquilla, Colombia. ${ }^{5}$ Allergy Unit, Fundacion Valle del Lili, Carrera 98 \# 18-49, Cali, Colombia.

Received: 10 September 2014 Accepted: 14 November 2014 Published online: 31 December 2014

\section{References}

1. Greaves MW: Chronic urticaria. N Engl J Med 1995, 332(26):1767 72.

2. Gaig P, Olona M, Mu?oz Lejarazu D, Caballero MT, Dom?nguez FJ, Echechipia S, Garc?a Abujeta JL, Gonzalo MA, Lleonart R, Mart?nez C?cera C, Rodr?guez A, Ferrer M:Epidemiology of urticaria in Spain. J Investig Allergol Clin Immunol 2004, 14(3):214 20.

3. Bergstrom KG: Chronic Urticaria: Omalizumab and Review of Therapeutic Options. J Drugs Dermatol 2013, 12(6):715 6

4. Kulthanan K, Jiamton S, Thumpimukvatana N, Pinkaew S: Chronic idiopathic urticaria: prevalence and clinical course. J Dermatol 2007, 34(5):294 301.

5. Nam YH, Kim JH, Jin HJ, Hwang EK, Shin YS, Ye YM, Park H-S: Effects of omalizumab treatment in patients with refractory chronic urticaria. Allergy Asthma Immunol Res 2012, 4(6):357 61

6. Saini SS: Chronic Spontaneous Urticaria: Etiology and Pathogenesis. Immunol Allergy Clin North Am 2014, 34(1):33 52

7. Maurer M, Weller K, Bindslev-Jensen C, Gimenez-Arnau A, Bousquet PJ, Bousquet J, Canonica GW, Church MK, Godse KV, Grattan CE, Greaves MW, Hide M, Kalogeromitros D, Kaplan AP, Saini SS, Zhu XJ, Zuberbier T: Unmet clinical needs in chronic spontaneous urticaria. A GA(2)LEN task force report. Allergy 2011, 66(3):317 30.

8. Zuberbier T, Aberer W, Asero R, Bindslev-Jensen C, Brzoza Z, Canonica GW, Church MK, Ensina LF, Gim?nez-Arnau A, Godse K, Gon?alo M, Grattan C, Hebert J, Hide M, Kaplan A, Kapp A, Abdul Latiff AH, Mathelier-Fusade P, Metz M, Saini SS, S?nchez-Borges M, Schmid-Grendelmeier P, Simons FE, Staubach P, Sussman G, Toubi E, Vena GA, Wedi B, Zhu XJ, Nast A, Maurer M: Methods report on the development of the 2013 revision and update of the EAACI/GA2 LEN/EDF/WAO guideline for the definition, classification, diagnosis, and management of urticaria. Allergy 2014, 69(7):e1 e29.

9. Franc?s L, Leiva-Salinas M, Silvestre JF: Omalizumab in the treatment of chronic urticaria. Actas Dermosifiliogr 2014, 105(1):45 52.

10. Lef? vre AC, Deleuran M, Vestergaard C: A long term case series study of the effect of omalizumab on chronic spontaneous urticaria. Ann Dermatol 2013, 25(2):242 5

11. Corren J, Casale TB, Lanier B, Buhl R, Holgate S, Jimenez P: Safety and tolerability of omalizumab. Clin Exp Allergy 2009, 39(6):788 97.

12. Kaplan AP, Popov TA: Biologic agents and the therapy of chronic spontaneous urticaria. Curr Opin Allergy Clin Immunol 2014, 14(4):347 53.

13. Finlay AY, Khan GK: Dermatology Life Quality Index (DLQI) a simple practical measure for routine clinical use. Clin Exp Dermatol 1994, 19(3):210 6.

14. Valero A, Herdman M, Bartra J, Ferrer M, Jauregui I, Davila I, del Cuvillo A, Montoro J, Mullol J, Sastre J, Canonica GW, Baiardini I: Adaptation and validation of the Spanish version of the Chronic Urticaria Quality of Life 
Questionnaire (CU-Q2oL). J Investig Allergol Clin Immunol 2008, 18(6):426 32.

15. Mlynek A, Magerl M, Hanna M, Lhachimi S, Baiardini I, Canonica GW, Brzoza Z, Kasperska-Zajac A, Rogala B, Zalewska-Janowska A, Zuberbier T, Maurer M: The German version of the Chronic Urticaria Quality-of-Life Questionnaire: factor analysis, validation, and initial clinical findings. Allergy 2009, 64(6):927 36.

16. Medical Search Terms Omalizumab [Available from: https://www.dropbox. com/s/8hhaisftmbxx4iy/search_strategy_\%283\%29\%5B1\%5D.pdf?dl=0]

17. Higgins J, Green S: Manual Cochrane de revisiones sistemticas de intervenciones. [Available from: http://es.cochrane.org/sites/es.cochrane. org/files/uploads/Manual_Cochrane_510_reduit.pdf]

18. Kaplan AP, Joseph K, Maykut RJ, Geba GP, Zeldin RK: Treatment of chronic autoimmune urticaria with omalizumab. J Allergy Clin Immunol 2008, 122(3):569 73

19. Maurer M, Rosen K, Hsieh HJ, Saini S, Grattan C, Gimenez-Arnau A, Agarwal S, Doyle R, Canvin J, Kaplan A, Casale T: Omalizumab for the treatment of chronic idiopathic or spontaneous urticaria. N Engl J Med 2013, 368(10):924 35.

20. Maurer M, Altrichter S, Bieber T, Biedermann T, Brautigam M, Seyfried S, Brehler R, Grabbe J, Hunzelmann N, Jakob T, Jung A, Kleine-Tebbe J, Mempel M, Meurer M, Reich K, Ru?ff F, Sch?kel K, Sengupta K, Sieder C, Simon JC, Wedi B, Zuberbier T, Mahler V, Staubach P: Efficacy and safety of omalizumab in patients with chronic urticaria who exhibit lgE against thyroperoxidase. J Allergy Clin Immunol 2011, 128(1):202 9. e5.

21. Saini S, Rosen KE, Hsieh H-J, Wong DA, Conner E, Kaplan A, Spector S, Maurer M: A randomized, placebo-controlled, dose-ranging study of single-dose omalizumab in patients with $\mathrm{H} 1$-antihistamine refractory chronic idiopathic urticaria. J Allergy Clin Immunol 2011, 128(3):567 73. e1.

22. Kaplan A, Ledford D, Ashby M, Canvin J, Zazzali JL, Conner E, Veith J, Kamath N, Staubach P, Jakob T, Stirling RG, Kuna P, Berger W, Maurer M, Ros?n K: Omalizumab in patients with symptomatic chronic idiopathic/ spontaneous urticaria despite standard combination therapy. J Allergy Clin Immunol 2013, 132(1):101 9.

23. Saini SS, Bindslev-Jensen C, Maurer M, Grob J-J, Bulbul Baskan E, Bradley MS, Canvin J, Rahmaoui A, Georgiou P, Alpan O, Spector S, Ros?n K: Efficacy and Safety of Omalizumab in Patients with Chronic Idiopathic/Spontaneous Urticaria Who Remain Symptomatic on H1 Antihistamines: A Randomized, Placebo-Controlled Study. J Invest Dermatol 2014, in press.

\section{Submit your next manuscript to BioMed Central and take full advantage of:}

$\nabla$ Convenient online submission

$\otimes$ Thorough peer review

$\otimes$ No space constraints or color $₫$ gure charges

$\triangle$ Immediate publication on acceptance

$\triangle$ Inclusion in PubMed, CAS, Scopus and Google Scholar

$\otimes$ Research which is freely available for redistribution 